\title{
Effects of command and guided discovery teaching styles on acquisition and retention of the handstand
}

http://dx.doi.org/10.11606/1807-5509202000010011

\section{Abstract}

The influential Mosston's Spectrum of Teaching Styles is a guide to teaching decisions in Physical Education. This highly researched topic has been tested in many contexts so that our focus is centered on the type of skill during motor skill acquisition in physical education settings. Given that the tasks employed in the studies have been either specialized or manipulative fundamental skills, we sought to extend our understanding of the issue addressing the effects of teaching styles in the process of learning a stability fundamental skill. Our purpose was to examine motor and psychological effects of command and guided discovery teaching styles from Mosston's Spectrum in the acquisition and retention of the handstand in scholars. Third graders from a suburban school in Sao Paulo, Brazil, were assigned to a command $(n=22)$ and a guided discovery $(n=23)$ group. The process of learning the handstand lasted six acquisition sessions, carried out between a pretest and a posttest/retention. We used as dependent variables the motor developmental level (initial, elementary and mature), the movement ratings (scores from 0 to 10) and the motivation levels (post-learning self-reported subscales from the Intrinsic Motivation Inventory). The guided discovery teaching style led more scholars to reach the mature developmental stage of the handstand on retention compared to the command teaching style. No group differences were detected with respect to ratings or intrinsic motivation. Regardless of the group, the pretest ratings were lower than the posttest ones as well as boys scored higher in pressure and tension subscale as compared to girls. The current findings suggest that both teaching styles promoted motor acquisition, but the guided discovery teaching style seemed to yield superior handstand retention.

KeYwords: Physical Education; Didactics; Pedagogy; Motor Learning; Motor Skill; Motivation.

\section{Introduction}

Teaching practices in physical education have strongly been influenced by the remarkable Mosston's framework of teaching styles ${ }^{1}$. The framework was originally proposed fifty years $\mathrm{ago}^{2}$ and comprises a spectrum which includes eleven teaching styles, command (A), practice (B), reciprocal (C), self-check (D), inclusion (E), guided discovery $(\mathrm{F})$, convergent discovery $(\mathrm{G})$, divergent production $(\mathrm{H})$, learner-designed individual program $(\mathrm{I})$, learner-initiated $(\mathrm{J})$, and self-teaching $(\mathrm{K})$.

Reproductive styles (A-E cluster) are teacher- centered because the teacher makes the decisions and set the goals while the students reproduce the teacher's knowledge trying to achieve the goals. Reproduction of knowledge and skills are known to the teacher and/or learner, the subject matter is concrete, there is one correct way to perform the task by emulation of the model, time is needed for practice, the cognitive operations involves memory and recall, feedback is specific and refers to the performance, individual differences acceptance is limited to physical and emotional boundaries, and repetition
*Escola do Estado de São Paulo, São Paulo, SP, Brasil.

**Escola de Artes, Ciências e Humanidades, Universidade de São Paulo, São Paulo, SP, Brasil.

***Universidade São Judas Tadeu, São Paulo, SP, Brasil. 
and reduction of errors compose the learning environment. Productive styles (F-K cluster) are student-centered as the student plays an active role in the process of learning, making decisions and producing knowledge and new skills. The subject matter is variable, there is no single model to emulate, time is needed for the cognitive processes involved and to evolve an effective learning environment which is of searching and examining the validity of alternatives going beyond the unknown, the emphasis is on cognitive operations of comparing, contrasting, problem solving and inventing, the process is discovery- and creativity-oriented, feedback does not refer to a single solution, and individual differences are broadly considered in terms of quantity, rate and kind ${ }^{3}$.

Mosston's spectrum is thought to be helpful not only to teachers in terms of their values and personal characteristics to fit objectives and behaviors but also to help students since the choice of a style can be tailored to their individual differences. The spectrum has been understood as a non-opposing notion in the sense that there is no better or worst style but the proper style to reach the goals of a given context. As the spectrum is a versatile tool through which pedagogical creativity and individuality can be expressed, the teacher may choose the style that fits best his/her own preferences, needs and goals ${ }^{1-6}$.

The noticeable success of the spectrum has generated many studies that have been undertaken to test its assumptions in teaching and learning contexts. However, the ensemble of studies that investigated Mosston's teaching styles on motor skill acquisition in physical education settings depicts mixed results (manipulative skills ${ }^{7}$; soccer skills $^{4,8}$; rifle-shooting ${ }^{9}$; golf putting ${ }^{10}$; football kicking $^{11}$; volleyball skills ${ }^{12}$ ). The majority of these studies employed specialized skills ${ }^{13}$, while only two of them ${ }^{7,11}$ were conducted with individuals performing fundamental skills.

A fundamental skill is divided into three developmental stages ${ }^{13}$. Two-year-old children show an initial movement pattern which is the child's first goal orientated attempts at performing a fundamental skill. This stage is characterized by missing out sequence parts of the skills, restricting or exaggerating the use of the body and a showing poor rhythmical flow.
The elementary stage is aimed at three or four year olds. The children develop control and rhythmical co-ordination of fundamental skills, but their movement patterns are still generally restricted or exaggerated. The mature stage is achieved by children of five or six years of age who can perform fundamental skills with mechanical efficiency and high co-ordination and control.

If we focus on the studies with fundamental skills ${ }^{7,11}$, we find that the participants performed the movements with their hands and feet, that is, manipulative skills. As only this category of movements has been studied in the spectrum's literature, we sought to address the effects of teaching styles on a stability fundamental skill. The handstand is a fundamental stability skill and one of the most important physical education contents of the Brazilian third grade ${ }^{14}$. The adequate onset of handstand practice is at six years of age and the fundamental requirements of it are posture and static balance ${ }^{13}$. The body must assume an upside-down configuration for a while before the movement is discontinued; the line of gravity must be within the base of support in the inverted posture as well as in the erect standing posture when the movement ends; the base of support involves head, hands, forearms, or upper arms and the shoulders are above the point of support.

Thus, in order to broaden our knowledge on Mosston's reproductive and productive teaching styles clusters, this study aimed to examine motor and psychological effects of command (reproductive) and guided discovery (productive) teaching styles on the handstand's acquisition and retention by third grade elementary scholars. We measured as dependent variables the amount of scholars on one of three developmental levels (initial, elementary and mature), the ratings given by experts regarding movement's quality, and the post-learning intrinsic motivation levels. Our hypothesis was defined on the grounds of the statement according to which skill acquisition has been related with reproductive styles because there is a specific task to learn and teach ${ }^{9}$. We expect therefore that skill acquisition and retention would be superior under the reproductive "command" style than under the productive "guided discovery" one. 


\section{Method}

\section{Participants and Groups}

Forty-five third grade scholars ( 18 boys and 27 girls) participated. Ages ranged from 8 to 10 years (mean $=8.71 ; \mathrm{SD}=0.47$ years). Ten boys and 12 girls were assigned to the command group, whereas eight boys and 15 girls were assigned to the guided discovery group. They were regular students from a suburban public school in the city of São Paulo, Brazil. All participants consented and received the consent from their parents/legal tutors by signing a consent form approved by the University Ethics Committee. None of the participants showed physical disorders or had any prior experience with the task.

\section{Task and Instruments}

We used Gallahue's developmental sequence checklist of the handstand ${ }^{13}$, as follows. In the initial stage, the child is able to maintain triangular, low-level, three-point balance positions and also to assume inverted three-point postures for up to three seconds, poor kinesthetic feel for unseen body parts, and minimal co-ordinate control of movements. In the elementary stage, the child can maintain controlled triangular three-points and low two-point contacts with surface, is able to hold balance for three seconds or longer with frequent brief addition of another balance point, and there is gradual improvement in monitoring of unseen body parts. In the mature stage, the child shows good surface contact position, good control of head and neck, good kinesthetic feel for body part location, appears to be in good control of body, maintains inverted low- and high-level two- and three-point balance positions for three or more seconds, and comes out of static posture under control.

The handstands performed in the tests (pretest, posttest and retention) were videotaped for further analysis on the developmental stages. Movements were also rated from 0 to 10 by trained observers regarding movement's quality. Trained observers performed both analyses according to Gallahue's checklist ${ }^{13}$.

In addition to motor performance variables, we believe that it is also important to scrutinize the effects of teaching styles on scholars' motivation since this psychological variable has been pointed out as a crucial factor to elicit effort, interest and positive behaviors in physical education settings ${ }^{15}$. We thus measured intrinsic motivation after the learning process by the application of a Portuguese version of the Intrinsic Motivation Inventory (IMIp) ${ }^{16}$, whose psychometric properties giving evidence to validity and reliability for Portuguese speakers' samples were described in a previous study ${ }^{17}$ carried out with scholar children. IMIp is composed of four subscales enjoy/interest, perceived competence, effort/importance and pressure/tension.

\section{Design, Procedure and Equipment}

A single physical education teacher was responsible for the 7-week intervention program. Despite two groups were formed (command and guided discovery), our unit of analysis was the learner so that the teacher planned and acted according to the teaching style at hand. Following Mosston's principles, ten lessons were planned for each group. The lessons were taught twice a week for 50 minutes. Lesson 1 was devoted to the pretest. Lessons 2 to 7 covered the specific programs (command or guided discovery) of the handstand acquisition. A post-test was administered 72 hours later (lesson 8) and, after one week from lesson 8, we applied a retention test (lesson 9). In lesson 10 the participants responded the IMIp individually with the help of the teacher. Movement patterns performed in lessons 1, 8 and 9 were filmed for subsequent analysis and comprised of three trials of the handstand.

The scholars performed from 20 to 30 trials of the handstand in the acquisition lessons (2 to 7), which were structured according to Mosston's decision categories: pre-impact set (10 minutes), impact set (30 minutes) and post-impact set (10 minutes). The main goal was the headstand from lessons 2 to 3 and the handstand from lessons 4 to 7 . We highlighted goals and demonstrations on pre-impact set. If the scholar required this information during the impact phase, the teacher provided it as many times as required. When provided, feedback was verbal and immediate. General feedback was given to all students on post-impact set.

For the command group, actions were established by the teacher as follows: 1 - Pre-impact: setting 
the practice environment with benches, plinth and mattresses, clarifying the aims and demonstrating the task by means of a figure and verbal instruction; 2 - Impact (based on the pedagogical sequence of the handstand $\left.{ }^{18}\right)$ : performing familiarization trials of the headstand (three-point inverted support), trials of headstand with a few elements of the handstand, trials of the headstand with several elements of the handstand, three familiarization trials of the handstand, trials of the handstand with increasing levels of complexity; 3 - Post-impact: cooling down and information supply about general performance.

The teacher's actions for the guided discovery group were conducted by: 1 - Pre-impact: setting the practice environment with benches, plinth and mattresses, providing cues and questions to the scholars with the purpose to guide them towards the aims, clarifying the aims and demonstrating the task by means of a figure and verbal instruction; 2 - Impact: guiding scholars in a process of discovering answers by using questions based on the pedagogical sequence of the handstand ${ }^{18} ; 3-$ Post-impact: cooling down and information supply about general performance.

\section{Results}

\section{Developmental Stages}

Observation and classification of developmental levels and ratings movements from the video recordings were performed by two independent observers. Inter-observer reliability scores were calculated from the main data. The percentage of agreements and Cohen's kappa (k) from the developmental levels were $84 \%$ and .50 , respectively. The intraclass correlation coefficient (Cronbach's alpha) from the ratings was .90. To handle the disagreements between observers, a trained experimenter identified all trials whose scores were different, assessed them and decided for the final score.

TABLE 1 displays the absolute frequencies for the groups in the developmental stages on each test. On pre-test, the number of children in the initial stage were significant higher than the number of children in the other two stages command group: $\mathrm{X}^{2}(1)=13.24 ; \mathrm{p}=0.0003$; guided discovery group: $\mathrm{X}^{2}(2)=26.004 ; \mathrm{p}=0.0003$. No

\section{Data Analysis}

The data from Gallahue's developmental stages (number of children in each stage) were organized in frequency distribution tables and analyzed inferentially by adherence chi-square tests. As three test movements were performed for each scholar, we chose to use the mode as a statistical measure for analysis. Ratings and motivation data were submitted to exploration to identify extreme outliers and normality of distribution. Subsequently means and standard deviations were calculated and, after checking for the assumption of homogeneity of variance, we run for the ratings a two-way analysis of variance (ANOVA), group (2) $x$ test (3), with repeated measures on test. For the motivation variables, we performed a one-way multivariate analysis of variance (MANOVA). When appropriate, F-ratios were reported with the degrees of freedom adjustments. Partial eta-squared values $\left(\eta^{2}\right)$ were reported for the effect sizes. Followup testing was conducted using Bonferroni post hoc procedures. For all analyses, alpha was set at .05 . Data were analyzed with the statistical software SPSS, version 23.

differences were detected in the post-test as to the number of children in the three developmental stages - command group: $\mathrm{X}^{2}(2)=4.45 ; \mathrm{p}=0.11$; guided discovery group: $\mathrm{X}^{2}(2)=1.13 ; \mathrm{p}=0.57$. On retention, for the command group the number of children in the initial stage was higher than the number of children in the elementary and mature stages $\left[\mathrm{X}^{2}(2)=9.36 ; \mathrm{p}=0.0009\right]$; for the guided discovery group, the number of children in the initial and mature stages was higher than the number of children in the elementary stage $\left[\mathrm{X}^{2}(2)=5.30 ; \mathrm{p}=0.05\right]$.

\section{Ratings}

Neither violations of normality of distribution nor extreme outliers were detected. Means and standard deviations are shown in TABLE 2. The ANOVA indicated a significant effect for the factor “test" $\left.\left[\mathrm{F}(2,70)=2.95 ; \mathrm{p}=0.05 ; \eta^{2}=0.08\right)\right]$. Even though, the effect size is smaller than medium, it is not trivial. The Bonferroni post hoc test showed 
that pre-test values were lower than post-test and retention ones. Neither the factor "group" nor the interaction "group $\mathrm{x}$ test" showed statistical significant effects.

\section{Motivation}

Means and standard deviations of motivation variables are displayed in TABLE 3. Although the subscale of interest/enjoyment had shown descriptive lower values in comparison to the other subscales, the MANOVA did not detect any significant differences among total or subscales scores. When the sample was rearranged by gender, the analysis indicated that boys and girls scored similarly in all variables, with the exception of the subscale pressure/tension, in which boys scored higher than girls $[\mathrm{F}(4,38)=3.47 ; \mathrm{p}=0.017$; $\left.\left.\eta^{2}=0.27\right)\right]$. This value of effect size is not high but it is reasonable to attest substantive significance.

TABLE 1 -Absolute frequencies distribution of scholars for command (CO) and guided discovery (GD) groups in the developmental stages.

\begin{tabular}{lcccccc}
\hline \multirow{2}{*}{$\begin{array}{c}\text { Developmental } \\
\text { Stage }\end{array}$} & \multicolumn{2}{c}{ Pre-test } & \multicolumn{2}{c}{ Post-test } & \multicolumn{2}{c}{ Retention } \\
\cline { 2 - 7 } \multicolumn{1}{c}{ CO } & GD & CO & GD & CO & GD \\
\hline Initial & $16^{*}$ & $18^{*}$ & 12 & 10 & $14^{*}$ & 12 \\
Elementary & 1 & 1 & 5 & 7 & 5 & $3^{\wedge}$ \\
Mature & 0 & 2 & 5 & 6 & 3 & 8 \\
Missing Date & 5 & 2 & 0 & 0 & 0 & 0 \\
\hline
\end{tabular}

TABLE 2 -Ratings' means and standard deviations for command (CO) and guided discovery (GD) groups.

\begin{tabular}{cccccc}
\hline \multicolumn{2}{c}{ Pre-test* } & \multicolumn{2}{c}{ Post-test } & \multicolumn{2}{c}{ Retention } \\
\hline CO & GD & CO & GD & CO & GD \\
\hline $3.67 \pm 1.58$ & $3.85 \pm 1.70$ & $4.1 \pm 1.30$ & $4.59 \pm 1.89$ & $3.85 \pm 1.52$ & $4.84 \pm 2.20$ \\
\hline
\end{tabular}

* pre-test x post-test/ retention $(p=.05)$

TABLE 3 -Motivation variables' means and standard deviations for command (CO) and guided discovery (GD) groups.

\begin{tabular}{lcc}
\hline & CO & GD \\
\hline Interest/ Enjoyment & $9.34 \pm 0.66$ & $9.42 \pm 0.51$ \\
Perceived/ Competence & $8.28 \pm 0.77$ & $8.34 \pm 1.28$ \\
Effort/ Importance & $9.13 \pm 1.13$ & $9.23 \pm 0.80$ \\
Pressure/ Tension & $6.53 \pm 2.06$ & $7.68 \pm 1.88$ \\
\hline
\end{tabular}

\section{Discussion}

This study attempted to investigate the effects of two Mosston's teaching styles - command and guided discovery - in the acquisition and retention of the handstand in third grade elementary scholars. The spectrum of teaching styles works with the axiom that teaching behavior is a chain of decision making. The two styles chosen for the present study bear different characteristics and objectives in a teaching-learning process. The command style represents a direct teaching style centered around the reproduction of knowledge, while the guided discovery style is an indirect teaching style whose focus is on the production of knowledge $e^{1-3,6}$.

Rather than productive, reproductive teaching styles are preferable when learning and teaching a specific task in a skill acquisition context ${ }^{9}$. Our hypothesis was based on this assumption so that it was our expectation that acquisition and retention performance would be superior
* initial x elementary/ mature $(p<.05)$ $\wedge$ elementary $\mathrm{x}$ initial/ mature $(\mathrm{p}=.05)$ 
under the command style when compared to the guided discovery style. The data analyses suggest the refutation of this hypothesis. Although no differences between groups were detected, the ratings given by the trained observers to the whole sample of scholars have substantially increased from the pretest to the posttest and retention. From a motor learning standpoint, retention means that after a period of rest the temporary residuals are dissipated so that motor behavior reflects a lasting effect of learning. This improvement suggests that motor learning has taken place ${ }^{19-21}$ and, accordingly, command and guided discovery styles seem to have elicited equivalent movement pattern enhancement throughout practice. This permanent learning effect was pointed out as a key point in studies aimed at establishing a relationship between motor skill acquisition and teaching styles ${ }^{7}$.

With regard to developmental stages, there appeared to be initial performance homogeneity as deduced by the vast majority of the children who began the experiment at the initial level of the handstand. The mature stage was achieved on retention by few scholars from the command group and by a significant number of children from the guided discovery group. We believe that the higher amount of scholars from the guided discovery group who reached the mature stage on retention supports the likelihood that discovering, rather than imposing, the pathways to proficiency entails considerable self-control practice which allowed the scholars to engage in more active processes of solving motor problems. Even when a specific task is the goal of teaching and learning, patterns of behavior need not be imposed so that organization can arise from discovering good solutions through exploring intrinsic dynamics ${ }^{22}$. The advantage in favor of productive compared to reproductive teaching styles was also verified in other similar studies that applied a retention test by the end of the learning process, to cite, in the learning of reaching, kicking, throwing, and dribbling ${ }^{7}$, and in the learning of dribbling ${ }^{8}$. Favorable results to reproductive styles were only detected in studies that did not apply learning tests (retention and/or transfer), for example, golf putting $^{10}$, and volleyball skills ${ }^{12}$. Negative results were found in participants who performed the soccer juggling ${ }^{4}$. The rifle-shooting learning was the only one which showed superior retention performance for the command group ${ }^{9}$, however, the comparison was made not against productive styles but against two other adjacent reproductive styles (practice and reciprocal); it is worth noting though that the assumption of initial performance homogeneity seems to have been violated as higher pretest scores for the command group were reported.

Our additional data from intrinsic motivation self-reported answers failed to show any group differences regarding the subscales enjoy/interest, perceived competence, effort/importance and pressure/tension. Interestingly, regardless of teaching style (command and guided discovery), the scholars reported high scores for all variables of the IMIp, three positive (enjoy/interest, perceived competence, effort/importance) and one negative (pressure/tension). When the sample was stratified by gender, boys scored higher in pressure and tension than girls, which corroborates previous findings with children performing general skills in a physical education setting ${ }^{17}$. These results suggest that our scholars were highly motivated to perform the handstand and also that the task put more strain on our boys.

In summary, the educational significance takeaway from our study is twofold: (1) either command or guided discovery teaching style are likely to promote handstand acquisition in thirdgrader scholars; (2) compared to the command teaching style, the guided discovery teaching style seems to promote slightly superior retention performance probably because it provides thirdgraders a more active role during the learning process of the handstand (e.g., autonomy, movement control, and task engagement). We shall consider some limitations of the present study. The handstand is a complex fundamental motor skill so that it may have caused fear of performing and physical fatigue during a practice session, variables that were not controlled. Also, the motivation levels in the subscales of enjoy/interest, perceived competence, effort/ importance and pressure/tension were selfreported by the scholars and thus might have been affected by any untrue response. Finally, the quantity of acquisition practice might not have been the same for all scholars since we did not fully control the number of acquisition trials, which was set within a bandwidth of 20-30 trials per session. 


\section{Acknowledgements}

We are grateful to the scholars who took part in the study. We thank the Principal of the School EE Hermano Ribeiro da Silva, Sra. Marcia Aparecida Messias de Carvalho for having authorized data collection. We also thank The Secretaria Estadual de Educação do Estado de Sao Paulo for sponsoring the first author with a grant.

\section{Resumo}

Efeitos dos estilos de ensino comando e descoberta guiada na aquisição e retenção do apoio invertido

A influência do espectro de estilos de ensino de Mosston é um guia para as decisões de ensino em Educação Física. Este tópico altamente pesquisado foi testado em muitos contextos porém o nosso foco está centrado em um tipo de habilidade durante a aquisição de habilidades motoras em contextos de educação física. Tendo em conta que as tarefas utilizadas nos estudos foram ou especializadas ou habilidades fundamentais manipulativas, buscou-se ampliar a nossa compreensão do tema abordando os efeitos de estilos de ensino no processo de aprendizagem de uma habilidade fundamental de estabilização. Nosso objetivo foi examinar os efeitos motores e psicológicos dos estilos de ensino comando e descoberta guiada a partir do Espectro do Mosston na aquisição e retenção do apoio invertido em alunos. Os alunos da terceira série de uma escola suburbana em São Paulo, Brasil, foram distribuídos no grupo comando $(n=22)$ e no grupo descoberta guiada $(n=23)$. 0 processo de aprendizagem do apoio invertido durou seis sessões de aquisição, realizada entre um pré-teste e pós-teste/retenção. Nós utilizamos como variáveis dependentes o nível de desenvolvimento motor (inicial, elementar e maduro), as classificações de movimento (pontuação de 0 a 10) e os níveis de motivação (pós-aprendizagem subescalas de autorrelato do Inventário motivação intrínseca). 0 estilo de ensino descoberta guiada levou mais alunos a alcançar o estágio de desenvolvimento maduro do apoio invertido na retenção em comparação com o estilo de ensino de comando. Não foram encontrados diferenças entre os grupos com relação a avaliação ou a motivação intrínseca. Independentemente do grupo, as avaliações pré-teste foram menores do que os pós-teste, bem como meninos pontuaram mais em pressão e tensão subescala, em comparação com meninas. Os resultados atuais sugerem que ambos os estilos de ensino promovem a aquisição motor, mas o estilo de ensino descoberta guiada parecia produzir uma retenção superior no apoio invertido.

PalavRAS-Chave: Educação física; Didática; Pedagogia; Aprendizagem Motora; Habilidade Motora; Motivação.

\section{References}

1. Mosston M, Ashworth S. Teaching physical education (1st ed on line). Benjamin Cummings, San Francisco 2008.

2. Mosston M. Teaching physical education. Columbus: OH-Merrill, Columbus 1966.

3. Sicilia-Camacho A, Brown D. (2008). Revisiting the paradigm shift from the versus to the non-versus notion of Mosston's spectrum of teaching styles in physical education pedagogy: A critical pedagogical perspective. Physical Education and Sport Pedagogy, 2008, 13, 85-108.

4. Beckett $\mathrm{K}$. The effects of two teaching styles on college students' achievement of selected physical education outcomes. Journal of Teaching in Physical Education, 1990, 10, 153-169.

5. Jaakkola T, Watt A. Finnish physical education teacher's self-reported use and perceptions of Mosston and Ashworth's teaching styles. Journal of Teaching in Physical Education, 2011, 30, 248-262.

6. Goldberger M, Ashworth S, Byra M. Spectrum of teaching styles retrospective 2012. Quest, 2012, 64, 268-282.

7. Derri V, Pachta M. Motor skills and concepts acquisition and retention: A comparison between two styles of teaching. International Journal of Sport Science, 2007, 3, 37-47.

8. Arjuna, R, Jayachandran R. Effects of command and guided discovery teaching styles on retention of a psychomotor 
skill. Journal of Humanities and Social Science, 2012, 1, 27-32.

9. Boyce BA. The effects of three styles of teaching on university student's motor performance. Journal of Teaching in Physical Education, 1992, 11, 389-401.

10. Salter WB, Graham G. The effect of three disparate instructional approaches on skill attempts and student learning in an experimental teaching unit. Journal of Teaching in Physical Education, 1985, 4, 212-218.

11. Goldberger M, Gerney P. Effects of learner use of practice time on skill acquisition of fifth grade children. Journal of Teaching in Physical Education, 1990, 10, 84-95.

12. Sunay H R, Gunduz N, Dolasir S. The effects of different methods used in teaching basic volleyball techniques to physical education teacher candidates. International Journal of Physical Education, 2004, 41, 28-32.

13. Gallahue DL, Ozmun JC. Understanding motor development: Infants, children, adolescents, adults (6th ed.). McGraw-Hill, Boston 2006.

14. The Brazilian National Board of Education. National curriculum parameters: Physical education. 1997, Retrieved from portal.mec.gov.br/seb/arquivos/pdf/livro07.pdf.

15. Weinberg RS, Gould D. Foundations of sport and exercise psychology (6th ed). Human Kinetics, Champaign 2015.

16. Fonseca AM. Versão portuguesa do intrinsic motivation inventory (IMI): Inventário de motivação intrínseca (IMIp). [Portuguese version of the intrinsic motivation inventory (IMI)]. 1995, Unpublished paper. Fcdef, University of Porto.

17. Fonseca AM., Brito AP. Propriedades psicométricas da versão portuguesa do intrinsic motivation inventory (IMIp) em contextos de actividade física e desportiva. [Psychometric properties of the IMIp - Portuguese version - in sport and physical activity contexts]. Análise Psicológica, 2001, 19, 59-76.

18. Leguet J. As ações motoras em ginástica esportiva. [The motor actions in sport gymnastics]. Manole, São Paulo 1987.

19. Lee TD. Motor control in everyday actions. Human Kinetics, Champaign 2011.

20. Magill RA, Anderson D. Motor learning and control: Concepts and applications. McGraw-Hill Higher Education, New York 2015.

21. Schmidt RA, Lee TD. Motor control and learning: a behavioral emphasis. Human Kinetics, Champaign 2011.

22. Thelen E, Smith LB. A dynamic systems approach to the development of cognition and action. MIT Press, Cambridge 1994.

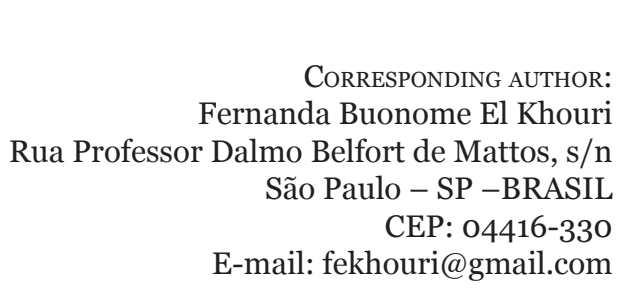

Submitted: 09/08/2016

1st. Review: 07/06/2017

Accepted: 03/08/2017 